\title{
Health Hazards of COVID-19 Travel-Related Quarantine for Older Adult
}

\author{
J. Woo ${ }^{1,2}$, S.S.Y. Yeung ${ }^{1}$

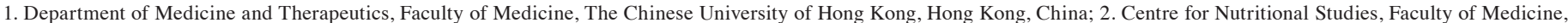 \\ The Chinese University of Hong Kong, Hong Kong, China.

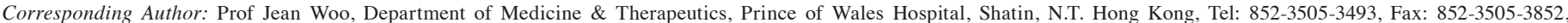 \\ Email: jeanwoowong@cuhk.edu.hk
}

\section{Dear Editor,}

$\mathrm{M}$ uch has been written about the adverse impact of public health measures on older adults in hospitals and long-term care settings (1). Many would agree that the risk of transmission in the context of long-term care may necessitate these measures. Yet little attention has been drawn to the well-functioning older adult who may need to travel across different countries for reasons other than leisure. A complex system of regulations need to be navigated, that aims to protect individual countries from introduction of the virus, particularly newly mutated versions that may be more easily transmitted. How these regulations are formulated vary from country to country, and is not predominantly guided by scientific considerations that take into consideration the epidemiology, the availability of genomic surveillance, and most importantly the science of risk management $(2,3)$. For some places there may be a dominant response of closing all borders or putting all arrivals into quarantine with frequent testing. For example, in response to the appearance of the Variant B.1.1.7 in the UK in December 2020, Hong Kong stopped all direct flights from the UK and banned all residents from returning if they have been in the UK for more than 2 hours within a period of three weeks before planned arrival, until early May 2021. In late April two special flights were arranged for stranded Hong Kong residents from UK, Brazil and South Africa to leave from London to return. At that time COVID 19 infections in the UK had dropped precipitously and vaccinations had covered over $50 \%$ of the populations, in contrast to the situation in South Africa and Brazil. Both flights were full and all 600 returnees had to be quarantined in the same hotel for 21 days, with all meals arranged to be delivered by an outside contractor. The windows and doors were not allowed to be opened (other than to receive meals) and the traveler was not allowed to leave the room.

This policy of grouping people deemed an infection risk together in order to 'centrally manage the infection risk', at the expense of increasing individual risk (grouping UK together with Brazil and South Africa simply based on the existence of variants and not taking into account the prevalence of infections; grouping all 600 people in two fully booked flights; and all quarantined in the same hotel the ventilation system of which may increase the risk of cross infection; raises an ethical issue, which a majority may argue is necessary for the common good perhaps. Yet these decisions should be based on the science of risk assessment. The latter had not been carried out.

As usual the needs of older adults have not been taken into account by public health measures, perhaps because of lack of knowledge or ageism. The importance of nutrition and physical activity in preventing age-related muscle loss- sarcopenia, now classified with an ICD code, with consequences such as falls and fractures clearly had not been considered. The size of the quarantine room is $136 \mathrm{sq} \mathrm{ft}$. It is largely occupied by 2 beds, allowing for a width of about 2 feet to walk from the door to the window (ten steps). Three meals were provided each day, labelled as Chinese, Western or Vegetarian (Table 1). The average calorie, protein and calcium are all below recommended values for bone and muscle health. The average protein provided each day was $47 \mathrm{~g}$. Taking a body weight of $65 \mathrm{~kg}$ as a reference, the daily recommended requirement is $78 \mathrm{~g}(1.2 \mathrm{~g} / \mathrm{kg}$ body weight), resulting in a total protein deficit of $650 \mathrm{~g}$ over 21 days. Together with reduced sun exposure and the lack of physical activity, this period will inevitably result in significant muscle loss. Although it is difficult to quantify, it has been documented that 10 days of inactivity result in loss of $1 \mathrm{~kg}$ of muscle (4), or a loss of $2 \mathrm{~kg}$ over the quarantine period. This would require at least few weeks of resistance exercises with protein supplementation to regain.

Table 1. Average nutrient content of food served during hotel quarantine in Hong Kong (5)

\begin{tabular}{|l|c|c|c|c|c|c|c|}
\hline & Energy & Protein & Carbohydrate & Fat & Saturated fat & Fibre & Calcium \\
\hline Daily* & $1270 \mathrm{kcal}$ & $47 \mathrm{~g}$ & $200 \mathrm{~g}$ & $30 \mathrm{~g}$ & $6 \mathrm{~g}$ & $15 \mathrm{~g}$ & $290 \mathrm{mg}$ \\
\hline Breakfast & $460 \mathrm{kcal}$ & $21 \mathrm{~g}$ & $57 \mathrm{~g}$ & $16 \mathrm{~g}$ & $4 \mathrm{~g}$ & $4 \mathrm{~g}$ & $115 \mathrm{mg}$ \\
Lunch & $400 \mathrm{kcal}$ & $13 \mathrm{~g}$ & $65 \mathrm{~g}$ & $9 \mathrm{~g}$ & $2 \mathrm{~g}$ & $3 \mathrm{~g}$ & $47 \mathrm{mg}$ \\
Dinner & $380 \mathrm{kcal}$ & $16 \mathrm{~g}$ & $78 \mathrm{~g}$ & $7 \mathrm{~g}$ & $1 \mathrm{~g}$ & $8 \mathrm{~g}$ \\
\hline
\end{tabular}

*Daily nutrient provision was calculated as the average of three days serving Western, Chinese and Vegetarian menu. Western menu provided higher quantity of macronutrients compared with Vegetarian and Chinese menu 
Food hygiene problems from the contractor providing meals also gave rise to epigastric pain and diarrhea for a few days.

These individual health considerations should be given equal importance to central surveillance of infection risk as well as affordability of quarantine concerns; health considerations should not take a secondary role to public health measures. The importance of nutrition and physical activity in older adults need to be placed firmly in the public health domain. Quarantine recommendations should include advice to carry out resistance exercises in an adequate space, and also protein supplementation if an outside contractor could not be relied on providing adequate nutrition and hygienic meals.

Conflicts of interest: The authors declare no conflicts of interest.

\section{References}

1. Lim WS, Liang CK, Assantachai P, Auyeung TW, Kang L, Lee WJ et al. COVID-19 and older people in Asia: Asian Working Group for Sarcopenia calls to actions. Geriatr Gerontol Int. 2020;20(6):547-558. doi: 10.1111/ggi.13939
2. Spiegelhalter D. Use of "normal" risk to improve understanding of dangers of covid19. BMJ. 2020;370:m3259. doi: 10.1136/bmj.m3259

3. Royal Statistical Society on Twitter (2021). One of the four tests that the government set for proceeding with the roadmap out of lockdown is that "our assessment of the risks is not fundamentally changed by new Variants of Concern" (A thread). https:// twitter.com/RoyalStatSoc/status/1394308231590301697. Accessed 21 May 2021.

4. Kortebein P, Ferrando A, Lombeida J, Wolfe R, Evans WJ. Effect of 10 days of bed rest on skeletal muscle in healthy older adults. JAMA 2007;297(16):1772-4. doi: 10.1001/jama.297.16.1772-b

5. Yang Y, Wang G, Pan X (2004). China Food Composition 2004. University Medical Press, Peking.

How to cite this article: J. Woo, S.S.Y. Yeung . Health Hazards of COVID-19 TravelRelated Quarantine for Older Adult. J Nutr Health Aging. 2021;25(7):944-945; http://

dx.doi.org/10.1007/s12603-021-1649-8 